\title{
Effect of deforestation on stream and spring water chemistry in Malinowski and Czyrna catchments in Beskid Ślq̨ski Mts.
}

\author{
Stanisław Małek ${ }^{1} \bowtie$, Katarzyna Krakowian ${ }^{1}$, Michał Jasik ${ }^{1}$, Katarzyna Dudek ${ }^{1}$, Martin Bátor ${ }^{2}$ \\ ${ }^{1}$ University of Agriculture in Krakow, Faculty of Forestry, Department of Forest Ecology, A1. 29 Listopada 46, \\ 31-425 Kraków, Poland, phone: +4812 6625077, e-mail: rlmalek@cyf-kr.edu.pl \\ 2 Technical University in Zvolen, Faculty of Forestry, Department of Silviculture, Masaryka 24, 96053 Zvolen, Slovakia
}

\section{Abstract}

Dieback of Norway spruce (Picea abies (L.) H. Karst) which has been observed in the Western Carpathians is of interest to scientists from many disciplines.. The aim of this study was to determine the impact of deforestation on water chemical composition in mountainous streams and springs. The research was carried out in 2004 and 2013 in two catchments of the Skrzyczne massif in the Silesian Beskid Mountains. Field studies included measurements of water $\mathrm{pH}$ and conductivity. Under laboratory conditions, there were determined concentrations: $\mathrm{Na}^{+}, \mathrm{K}^{+}, \mathrm{Ca}^{2+}$, $\mathrm{Mg}^{2+}, \mathrm{NH}_{4}^{+}, \mathrm{Cl}^{-}, \mathrm{NO}_{3}^{-}, \mathrm{SO}_{4}{ }^{2}$ in each water sample. The results of physical and chemical analyses of water collected within the Malinowski catchment (covered mainly with spruce stands) and on northern slopes of the Skrzyczne massif - within the Czyrna catchment (covered mainly with beech stands), showed higher contents of base cations when compared to deforested areas. The highest concentrations of the ions analysed were recorded within the Czyrna catchment. Such phenomena should be taken into consideration during forest reconstruction after spruce dieback.

\section{KeY WORDS}

afforestation, water chemistry, Western Carpathians

\section{INTRODUCTION}

Silesian Beskids (Beskid Śląski) located in southeastern part of Poland is one of the mountain ranges in the Outer Western Carpathians, Its highest peak - Skrzyczne (1257 m a.s.1.) - is built of sandstones, shales, and less frequently - conglomerates, marlstones and limestones, which form the Carpathian Flysch Belt. Godula sandstone has siliceous, calcifer- ous or clayeous binding cement, relatively resistant to weathering. In Malinowski and Czyrna catchments there are sandstones with rich admixture of thickcovered and slim-covered shales. Shale, clay and loam have very poor water-bearing abilities, while these of sandstone complexes and slates are much better and podsols are the main kind of soils. In lower parts of the Czyrna catchment, there occur typical podsolic cambisols. The relief of Skrzyczne range is influenced by 
water erosion due to differentiation of permeability of bedrock layers. There are many seasonal springs and streams with variable outflow regimes and no uniform groundwater horizons. After intensive rainfall some dry streams are changed into fast water streams but most often water escapes to the surface by infiltration or it overflows and various forms of temporary springs, such as: bog springs, leaks, seepages are formed (Małek and Krakowian 2009a,b; Małek et al. 2010). The Skrzyczne peak receives a relatively large amount of rainfall. Its annual precipitation ranges from 1200 $\mathrm{mm}$ up to $2000 \mathrm{~mm}$. For comparison, average precipitation for Poland is $600 \mathrm{~mm}$ per year (Nowak 2002).

The role of landscape structure is very important for landscape water management. Especially, changes of plant cover can affect not only the amount of water but also water chemistry. Chemistry of precipitation water is changed by passing and filtering through the plant cover, soil and bedrock. The landscape of the Silesian Beskid Mts. was originally composed of mixed tree stands (fir Abies alba Mill., beech Fagus sylvatica L., spruce Picea abies (L.) H. Karst, aspen Populus tremula L., alder Alnus incana (L.) Moench) or else homogenous spruce stands growing on the mountains. The plant cover changed significantly after planting prevalent spruce monocultures on allochtonic sites. Since 2006, spruce stands have been damaged by drought, bark beetles, pathogenic fungi and windthrows, which all had their share in dieback of spruce in this area. Mountain slopes, previously covered by Norway spruce stands in the upper forest zone and the lower subalpine zone have been destroyed (Małek et al. 2012). A similar process took place in other mountain areas in Central Europe. Deforestation affected water chemistry in a large part of Silesian Beskids springs (Sienkiewicz et al. 1995; Astel et al. 2008; Małek and Krakowian 2009a; Małek and Krakowian 2012), e.g. in 50\% of the Czyrna catchment and $73 \%$ of the Malinowski catchment (Małek et al. 2012) .

The aim of this study was to assess changes in spring water chemistry (cations and anions) and also other characteristics ( $\mathrm{pH}$ and conductivity) when compared in the years 2004 and 2013. The hyphothesis was tested that tree cover changes on catchment: beech and spruce stands and stands after spruce dieback (young spruce stands and areas without forest) can affect water chemistry.

\section{MAterial AND MEthodS}

The area of our interest is divided into two catchments of the Skrzyczne massif, called Roztoka Czyrna (northern slopes) and Zimnik (Malinowski stream) (southern slopes). Both belong to the Forest Districts of Bielsko and Węgierska Górka. These catchments do not have similar characteristics of soils, geological bedrock, altitude; and their exposition is also different (Astel et al. 2009; Małek and Krakowian 2009a,b).
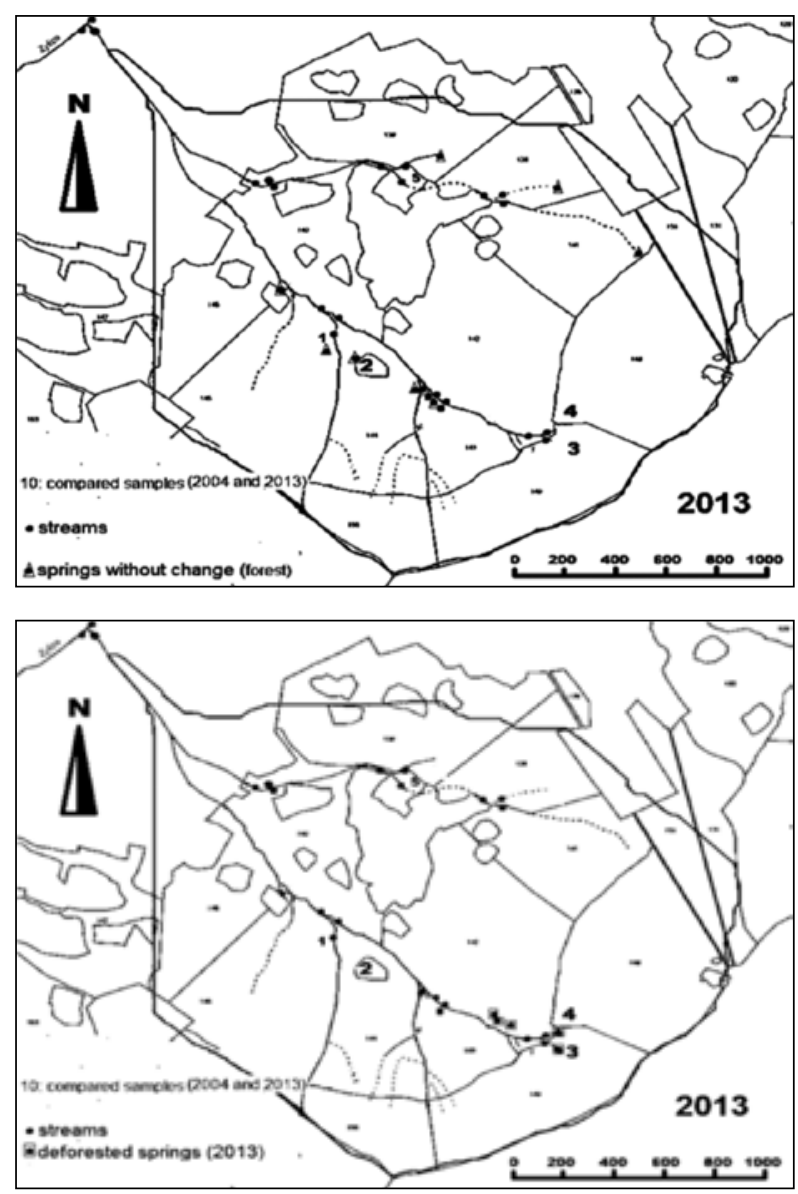

Figure 1. Sampling points in the Czyrna catchment

Water sampling was performed in October 2004 (before Norway spruce dieback) and October 2013 (after Norway spruce dieback which resulted in deforestation). The samples were collected from springs and streams within the area of the catchments: Czyrna and Malinowski. In 2004, water samples were taken from streams at 24 locations (Czyrna - 9, Malinowski - 15) 
and from springs at 29 locations (Czyrna - 11, Malinowski - 18). In 2013, water samples were collected in 43 places, from streams (21 Czyrna, 22 Malinowski) and in 27 places from springs (16 Czyrna, 11 Malinowski). The locations of sampling points are shown in figures 1 and 2. The occurrence of springs depends on actual climatic conditions, the season of year and other site characteristics. Thus, sampling points were not always the same in the years of observations, since quite a few of them just disappeared and several - appeared. Only some of the samples collected were from the same point in 2004 and 2013 year and these were taken into consideration in further analyses. Accordingly, there were compared 13 water samples from springs (Czyrna -3 , Malinowski -10 ) and 10 samples from streams (Czyrna - 2 and Malinowski-8).
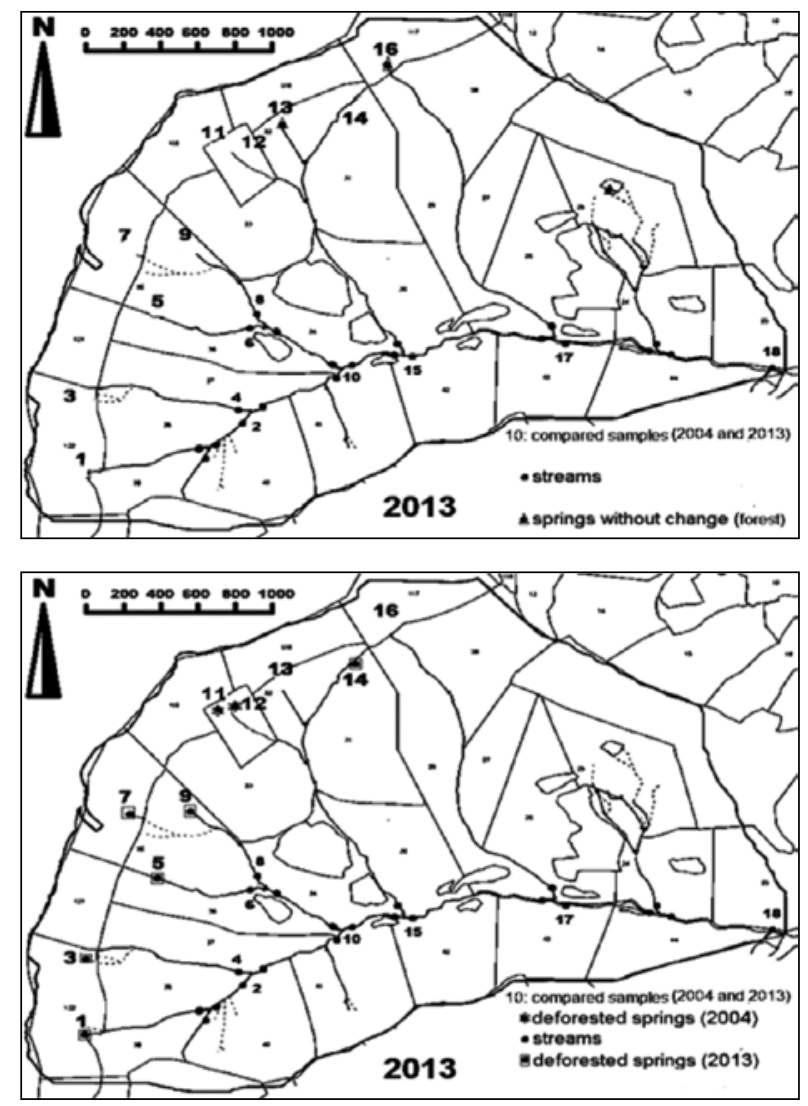

Figure 2. Sampling points in the Malinowski catchment

There were evaluated 5 water samples collected from Czyrna catchment deforested area in 2013, but only 2 of them were taken from the same sampling points as in 2004. On the Malinowski catchment were compared 18 deforested sites (2013) and all of them can be compared with 2004 and two points were deforested in 2004 and now (in 2013) there is a new forest and we can compare them too.

From each location, there were collected $100 \mathrm{ml}$ water samples. Sample temperature, $\mathrm{pH}$ and electrolytic conductivity were measured in the field using Eijkelkamp pH 13.37, EC 18.34 equipment. Next, the samples were processed in the laboratory of the Department of Forest Ecology, University of Agriculture in Krakow for chemical analysis. In each sample, there were determined the concentrations of $\mathrm{Na}^{+}, \mathrm{K}^{+}, \mathrm{Ca}^{2+}, \mathrm{Mg}^{2+}, \mathrm{NH}_{4}^{+}$, $\mathrm{Cl}^{-}, \mathrm{NO}_{3}{ }^{-}, \mathrm{SO}_{4}{ }^{2-}$ with the use of Dionex-320 system and Dionex-5000 chromatograph. Laboratory data-processing was based on the comparison of water samples collected within yet forested areas without forest coverage changes with the samples taken from springs and streams within deforested sites flowing through beech and spruce stands.

Statistical non-parametric analysis (KolmogorovSmirnoff test, $\mathrm{p}<0.05$ ) was performed to test statistically significant differences between the years 2004 and 2013.

\section{Results}

Water in the streams investigated was not affected by deforestation as much as that in the springs. Subsequent to deforestation in the Malinowski catchment, spring water became acidic. In deforested Czyrna catchment, water was also acidic, however after reforestation in 2010 its pH increased (fig. 3). In 2013, water conductivity values showed a wider range and no clear trend (fig. 4). After deforestation we noticed significant lower $\mathrm{SO}_{4}{ }^{2-}, \mathrm{pH}, \mathrm{NH}_{4}{ }^{+}$and not significant $\mathrm{Mg}^{2+}$ and $\mathrm{K}^{+}$concentration on the Czyrna catchment (tab. 1 and 3, fig. 5) and similar significant lower $\mathrm{SO}_{4}{ }^{2-}$ and $\mathrm{NH}_{4}{ }^{+}$were observed on the Malinowski catchment and for $\mathrm{Cl}^{-}-\mathrm{cf}$. (tab. 2 and 4, fig. 6).

Not all the differences in ion and cation concentration between the years 2004 and 2013 can be explained by deforestation in the Czyrna catchment (tab. 3). Ammonium, chloride and sulphate ion concentrations changed analogously both in deforested areas and in those where tree stands remained healthy. However, 


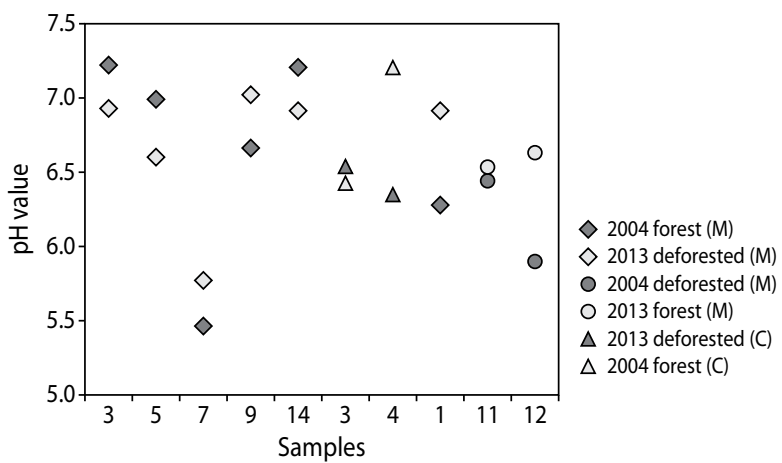

Figure 3. Changes of $\mathrm{pH}$ spring waters in forested and deforested areas (comparison water samples taken in the same location in 2004 and 2013; C - Czyrna, $\mathrm{M}$ - Malinowski catchment)

there was observed different behaviour of calcium. In the area without plant cover change, the concentration of calcium was at the same level in 2004 and 2013 (above $5 \mathrm{mg} / \mathrm{l}$ ), whereas in deforested areas it decreased (from 4.35 to $2.61 \mathrm{mg} / \mathrm{l}$ ). Conductivity values performed quite opposite: in the stable area water conductivity increased (from 69.10 to $80.38 \mu \mathrm{S} / \mathrm{cm}$ ) and in the dieback area it decreased (from 83.5 to $69.88 \mu \mathrm{S} / \mathrm{cm}$ ).

Not all the differences in ion and cation concentration between the years 2004 and 2013 can be explained by deforestation in the Malinowski catchment (tab. 4). The concentration of sodium ions in water increased in unchanged areas from 3.98 to $8.31 \mathrm{mg} / \mathrm{l}$. There also increased calcium cation and chloride anion concen-

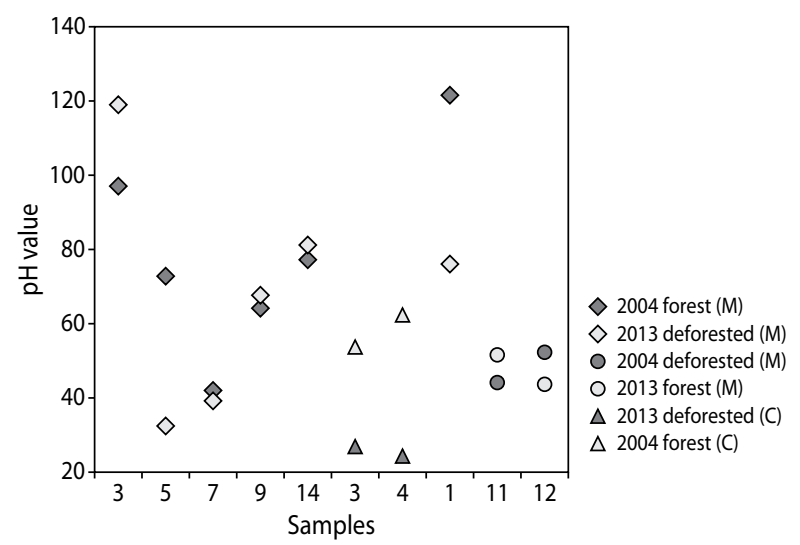

Figure 4. Changes of electrolytic conductivity in spring water in forested and deforested areas (comparison water samples taken in the same location in 2004 and 2013; C - Czyrna, M - Malinowski catchment)

trations. The increase of chloride anion concentration in water from not changed areas could be connected with human activities (domestic waste water and acid rain). In the area without plant cover change, the concentration of calcium increased between 2004 and 2013 (above 3,5 mg/l), whereas in deforested areas it decreased (from 1.68 to $1.40 \mathrm{mg} / \mathrm{l}$ ). Also conductivity behaves quite opposite - in stable area it became higher (from 85.50 to $142.2 \mu \mathrm{S} / \mathrm{cm}$ ) while in the dieback area it became lower (from 58.05 to $25.10 \mu \mathrm{S} / \mathrm{cm}$ ). Changes in ion concentrations are quite bigger in the Malinowski catchment compared to the Czyrna catchment.

Table 1. Statistically significant differences in the Czyrna catchment

\begin{tabular}{|c|c|c|c|c|c|c|c|}
\hline Variable & $\begin{array}{c}\text { Max. negative } \\
\text { difference }\end{array}$ & $\begin{array}{c}\text { Max. positive } \\
\text { difference }\end{array}$ & $\mathrm{p}$ & $\begin{array}{c}\text { Average } \\
\text { group 1 }\end{array}$ & $\begin{array}{c}\text { Average } \\
\text { group 2 }\end{array}$ & $\begin{array}{c}\text { St. dev. } \\
\text { group 1 }\end{array}$ & $\begin{array}{c}\text { St. dev. } \\
\text { group 2 }\end{array}$ \\
\hline $\mathrm{Na}^{+}$ & -0.222 & 0.333 & $\mathrm{p}>.1$ & 2.646 & 3.826 & 1.674 & 4.646 \\
\hline $\mathrm{NH}_{4}^{+}$ & $0.000^{*}$ & $1.000^{*}$ & $\mathrm{p}<.001^{*}$ & $1.086^{*}$ & $0.065^{*}$ & $0.541^{*}$ & $0.028^{*}$ \\
\hline $\mathrm{K}^{+}$ & -0.111 & 0.333 & $\mathrm{p}>.1$ & 0.929 & 0.726 & 0.315 & 0.311 \\
\hline $\mathrm{Ca}^{2+}$ & -0.555 & 0.111 & $\mathrm{p}>.1$ & 2.979 & 5.034 & 1.377 & 2.656 \\
\hline $\mathrm{Mg}^{2+}$ & 0.000 & 0.555 & $\mathrm{p}>.1$ & 1.927 & 1.026 & 0.890 & 0.525 \\
\hline $\mathrm{Cl}^{-}$ & -0.222 & 0.444 & $\mathrm{p}>.1$ & 2.028 & 8.583 & 0.540 & 14.962 \\
\hline $\mathrm{NO}_{3}^{-}$ & -0.222 & 0.222 & $\mathrm{p}>.1$ & 3.582 & 3.332 & 1.693 & 2.076 \\
\hline $\mathrm{SO}_{4}^{2-}$ & $0.000^{*}$ & $0.888^{*}$ & $\mathrm{p}<.005^{*}$ & $15.262^{*}$ & $9.416^{*}$ & $3.303^{*}$ & $2.383^{*}$ \\
\hline $\mathrm{H}^{+}$ & $-0.666^{*}$ & $0.000^{*}$ & $\mathrm{p}<.05^{*}$ & $0.159^{*}$ & $0.262^{*}$ & $0.140^{*}$ & $0.119^{*}$ \\
\hline $\begin{array}{c}\text { Electrical } \\
\text { conductivity }\end{array}$ & $-0.666^{*}$ & $0.222^{*}$ & $\mathrm{p}<.05^{*}$ & $74.733^{*}$ & $97.833^{*}$ & $22.040^{*}$ & $52.161^{*}$ \\
\hline
\end{tabular}

* Indicate significance level 

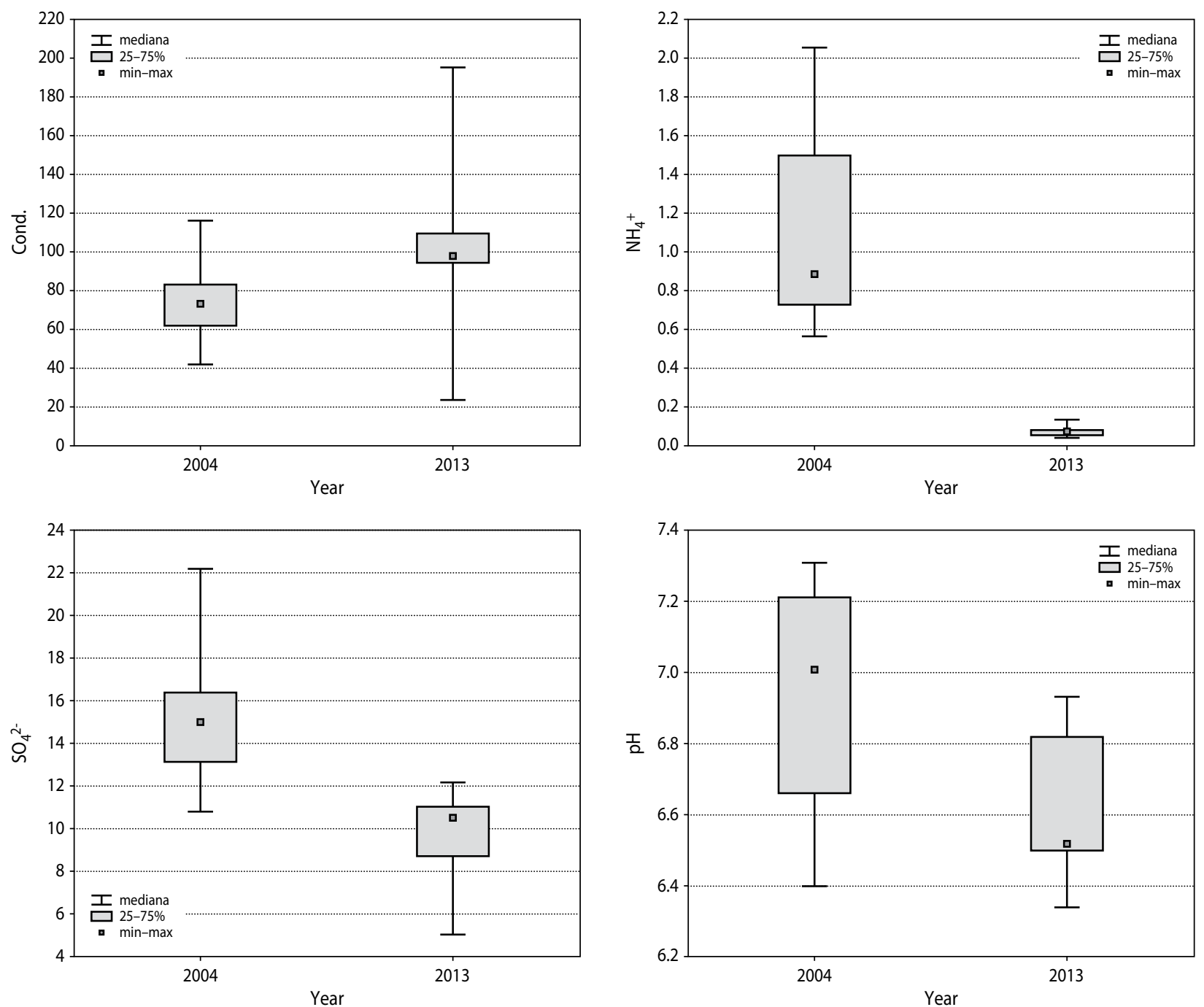

Figure 5. Box-and-whisker diagram for significant differences in the Czyrna catchment

Table 2. Statistically significant differences in the Malinowski catchment

\begin{tabular}{|c|c|c|c|c|c|c|c|}
\hline Variable & $\begin{array}{c}\text { Max. negative } \\
\text { difference }\end{array}$ & $\begin{array}{c}\text { Max. positive } \\
\text { difference }\end{array}$ & $\mathrm{p}$ & $\begin{array}{c}\text { Average } \\
\text { group 1 }\end{array}$ & $\begin{array}{c}\text { Average } \\
\text { group 2 }\end{array}$ & $\begin{array}{c}\text { St. dev. group } \\
1\end{array}$ & $\begin{array}{c}\text { St. dev. group } \\
2\end{array}$ \\
\hline $\mathrm{Na}^{+}$ & -0.438 & 0.313 & $\mathrm{p}<.10$ & 1.391 & 1.350 & 0.649 & 0.247 \\
\hline $\mathrm{NH}_{4}^{+}$ & $0.000^{*}$ & $1.000^{*}$ & $\mathrm{p}<.001^{*}$ & $0.784^{*}$ & $0.011^{*}$ & $1.107^{*}$ & $0.013^{*}$ \\
\hline $\mathrm{Ca}^{2+}$ & -0.375 & 0.188 & $\mathrm{p}>.10$ & 4.924 & 4.403 & 4.799 & 2.788 \\
\hline $\mathrm{Mg}^{2+}$ & 0.000 & 0.438 & $\mathrm{p}<.10$ & 1.159 & 0.725 & 0.574 & 0.271 \\
\hline $\mathrm{Cl}^{-}$ & $0.000^{*}$ & $1.000^{*}$ & $\mathrm{p}<.001^{*}$ & $1.717^{*}$ & $0.719^{*}$ & $0.496^{*}$ & $0.122^{*}$ \\
\hline $\mathrm{SO}_{4}^{2-}$ & $0.000^{*}$ & $1.000^{*}$ & $\mathrm{p}<.001^{*}$ & $14.733^{*}$ & $8.898^{*}$ & $1.888^{*}$ & $1.347^{*}$ \\
\hline $\mathrm{H}^{+}$ & -0.250 & 0.375 & $\mathrm{p}>.10$ & 2.974 & 0.246 & 9.847 & 0.392 \\
\hline $\begin{array}{c}\text { electrical } \\
\text { conductivity }\end{array}$ & -0.313 & 0.188 & $\mathrm{p}>.10$ & 71.050 & 72.981 & 18.897 & 23.875 \\
\hline
\end{tabular}

* Indicate significance level 

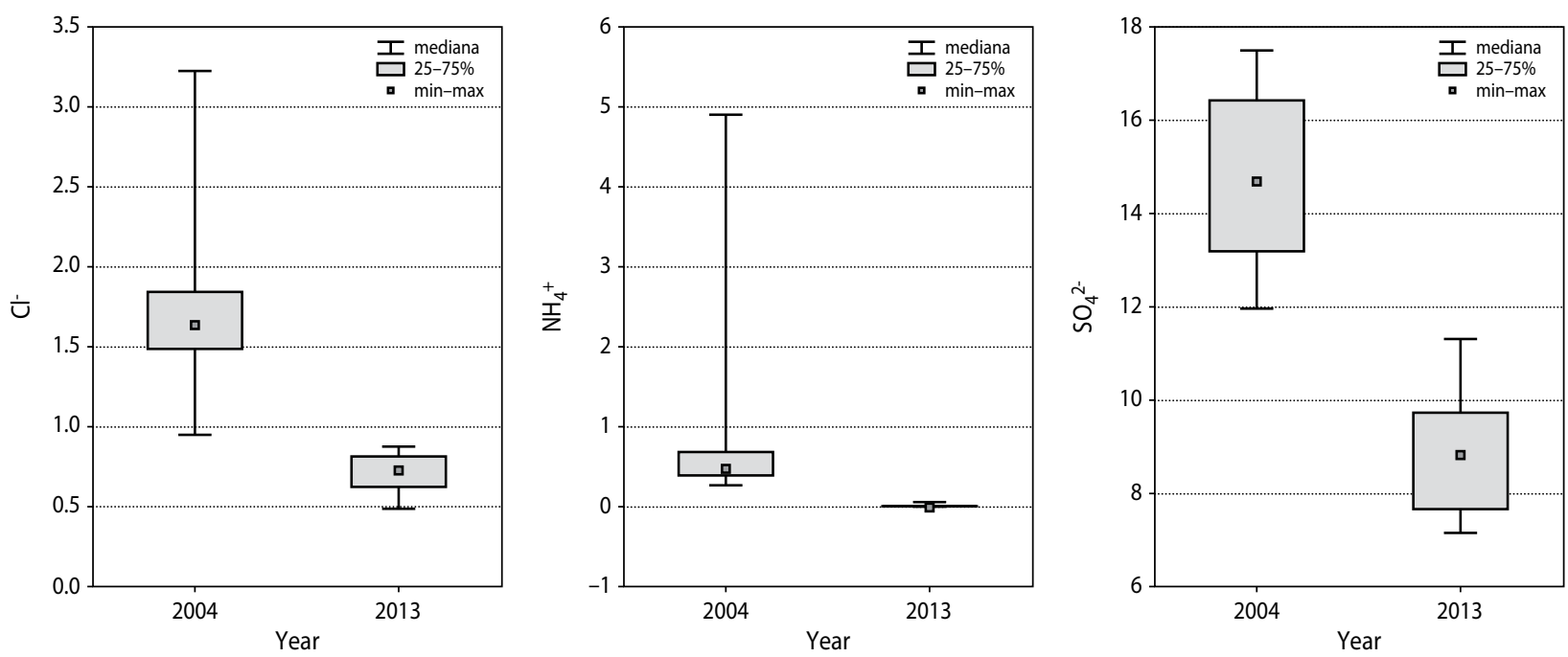

Figure 6. Box-and-whisker diagram for significant differences in the Malinowski catchment

Table 3. Comparison of ion concentrations, conductivity and $\mathrm{pH}$ in water samples in the years 2004 and 2013 according to plant cover in the Czyrna catchment

\begin{tabular}{|l|l|c|c|c|c|c|c|c|c|c|c|c|}
\hline \multicolumn{2}{|c|}{ Spring and area type } & $\mathrm{Na}^{+}$ & $\mathrm{NH}_{4}^{+}$ & $\mathrm{K}^{+}$ & $\mathrm{Ca}^{2+}$ & $\mathrm{Mg}^{2+}$ & $\mathrm{Cl}^{-}$ & $\mathrm{NO}_{3}^{-}$ & $\mathrm{SO}_{4}^{2-}$ & $\mathrm{F}^{-}$ & $\mathrm{pH}^{-} \begin{array}{c}\text { Electrical } \\
\text { conductivity }\end{array}$ \\
\hline \multirow{2}{*}{$\begin{array}{l}\text { Springs } \\
\text { without plant } \\
\text { cover change }\end{array}$} & forest 2004 & 1.51 & 0.54 & 0.66 & 5.81 & 1.17 & 1.76 & 2.96 & 14.76 & 0.00 & 5.32 & 69.10 \\
\cline { 2 - 32 } \\
\hline $\begin{array}{l}\text { Springs with } \\
\text { plant cover } \\
\text { change }\end{array}$
\end{tabular}

Table 4. Comparison of ion concentrations, conductivity and $\mathrm{pH}$ in water samples in the years 2004 and 2013 according to plant cover in the Malinowski catchment

\begin{tabular}{|c|c|c|c|c|c|c|c|c|c|c|c|c|}
\hline \multicolumn{2}{|c|}{ Spring and area type } & $\mathrm{Na}^{+}$ & $\mathrm{NH}_{4}^{+}$ & $\mathrm{K}^{+}$ & $\mathrm{Ca}^{2+}$ & $\mathrm{Mg}^{2+}$ & $\mathrm{Cl}^{-}$ & $\mathrm{NO}_{3}{ }^{-}$ & $\mathrm{SO}_{4}^{2-}$ & $\mathrm{F}^{-}$ & $\mathrm{pH}$ & $\begin{array}{c}\text { Electrical } \\
\text { conductivity }\end{array}$ \\
\hline \multirow{2}{*}{$\begin{array}{l}\text { Springs } \\
\text { without plant } \\
\text { cover change }\end{array}$} & forest 2004 & 3.98 & 0.83 & 0.98 & 3.62 & 2.35 & 1.68 & 3.45 & 16.94 & 0.00 & 6.91 & 85.50 \\
\hline & forest 2013 & 8.31 & 0.06 & 0.69 & 7.12 & 1.22 & 23.20 & 3.56 & 9.44 & 0.02 & 6.66 & 142.20 \\
\hline \multirow{2}{*}{$\begin{array}{l}\text { Springs with } \\
\text { plant cover } \\
\text { change }\end{array}$} & forest 2004 & 1.57 & 1.89 & 0.80 & 1.68 & 1.09 & 2.75 & 4.87 & 12.95 & 0.01 & 6.65 & 58.05 \\
\hline & $\begin{array}{l}\text { deforested } \\
\text { area } 2013\end{array}$ & 0.69 & 0.04 & 0.27 & 1.40 & 0.23 & 0.69 & 0.11 & 5.72 & 0.01 & 6.12 & 25.10 \\
\hline
\end{tabular}




\section{Discssion}

Rapid changes in the plant cover are one of the main factors in assessing long-term changes of surface? water chemistry. Deforestation caused reduction of ion contents in spring and stream water, which was also observed by Astel et al. (2009) in the Silesian Beskid Mts. These authors found lower concentrations of $\mathrm{Na}^{+}, \mathrm{K}^{+}$, $\mathrm{Mg}^{2+}, \mathrm{Cl}^{-}$and $\mathrm{SO}_{4}{ }^{2-}$ in spruce stands above $1,000 \mathrm{~m}$ a.s.l. As observed in our study - the authors noted that in lower parts of the catchment (mixed and beech stands, especially in the Czyrna catchment), water $\mathrm{K}^{+}, \mathrm{Cl}^{-}$, $\mathrm{Ca}^{2+}$ and $\mathrm{NO}_{3}{ }^{-}$concentrations were higher, whereas the values of water $\mathrm{pH}$ were lower. Higher concentrations of sulphates are typical for upper parts of the catchment (Siwek et al. 2013). All this applies to the areas without cover changes. The comparison of the results from 2004 and 2013 shows that ion concentrations after deforestation changed more specifically. Higher concentrations of chlorine anions in valley springs (Siwek et al. 2013) were confirmed, too.

Data from the year 2009 concerning the springs in the Czyrna and Malinowski catchments (Małek and Krakowian 2012) affected by spruce dieback, showed that water conductivity in springs in deforested areas was lower, and this was confirmed by our results from 2013. Increased concentrations of $\mathrm{NO}_{3}^{-}$anions and a decrease of cation concentrations after deforestation (Christopher et. al. 2006), in our results it is not so clear, as in stable tree stand $-\mathrm{NO}_{3}{ }^{-}$increased too. but this is not desirable for water quality. Małek and Krakowian (2009a) indicate that chemical features of water may to some degree be modified through structuring the composition of a tree stand, which was confirmed by higher concentrations of magnesium and sodium ions in waters from the sites in neighbouring multi-species deciduous tree stands.

Increasing concentrations of magnesium, calcium, potassium, sodium and ammonium cations and chlorine anions in spring and stream waters were attributed to the effects of spruce monoculture (Małek and Astel 2007; Astel et al. 2008). The acid neutralising capacity, alkalinity, and soil acidity were found to depend on the age of spruce stands (Małek 2009). Forest tree species composition has major influence on $\mathrm{N}$ cycling (Christopher et al. 2006). According to Siwek et al. (2013) the influence of ion concentrations depends on Carpathian
Flysh. For example, $\mathrm{Ca}^{2+}$ and $\mathrm{Mg}^{2+}$ concentrations in water are influenced by aquifer lithology, $\mathrm{SO}_{4}{ }^{2-}$ and $\mathrm{Cl}^{-}-$by various elevation and $\mathrm{NO}_{3}{ }^{-}-$by rainfall. Many local conditions cannot be influenced by human activity (weather, climatic factors, temperature extremes, leaching of soil nutrients after these periods, etc.). Tree species composition should be modified by using of appropriate silvicultural and treatment operations. It is necessary to increase the retention of basic elements, especially $\mathrm{Mg}^{2+}$ and $\mathrm{Ca}^{2+}$ (Małek 2009). Water chemistry of streams and springs is a good indicator of implemented practices. The process of reconstruction of spruce stand monocultures should be accelerated in the areas enriched with springs, and these areas should be used as natural ecosystems for mixed forests (Astel et al. 2008).

\section{Conclusions}

Water chemistry of mountain springs and streams is influenced by forest stands. The results of this study showed that stream waters were not affected by deforestation as mach as spring waters. Tree species, density and health conditions, silvicultural and harvesting operations in forest stands may have a very important role by creating of ion concentrations through water flow due to a rapid increase of mineralization of organic matter caused by the change of the hydrothermal surface of the basin. Spruce stand disintegration resulted in: $\mathrm{pH}$, $\mathrm{SO}_{4}{ }^{2-}$ and $\mathrm{NH}_{4}{ }^{+}$decrease in spring water but after reforestation water $\mathrm{pH}$ increased as well as the concentration of basic cations. Observed increasing proportion of nitrate anions after deforestation can be clear signals of an urgent need for changing tree composition in mountain areas.

In the area without plant cover, water conductivity and calcium concentration did not change, while in deforested area the values of these decreased. Concentrations of cations show higher values in forested areas with the dominance of beech stands.

Knowledge on the condition of mountain watershed areas as sources of drinking water is an important component of intended changes of forest stands in favour of mixed stands. The basis of water management must be supported by actual site conditions (the present structure of forests), and information on water chemi- 
cal elements and physicochemical properties should be included in any management strategy.

\section{ACKNOWLEDGements}

The present research was funded by Grant No. NSC - 2011/01/B/NZ9/04615 - The impact of deforestation caused by the ecological disaster on spatial variation and changes in the chemistry of spring water and surface water in the Beskid Ślaski Mts.

\section{References}

Astel A., Małek S., Makowska S. 2008. Effect of environmental conditions on chemical profile of stream water in sanctuary forest area. Water, Air an Soil Pollution, 195, 137-149.

Astel A., Małek S., Krakowian K. 2009. Multivariate exploration and classification applied to the chemical composition of spring waters in sanctuary forest areas. International Journal of Environmental Analytical Chemistry, 89 (8/12), 597-620.

Christopher S.F., Page D.B., Campbell J.L., Mitchell J.M. 2006. Contrasting stream water $\mathrm{NO}_{3}{ }^{-}$and $\mathrm{Ca}^{2+}$ in two nearly adjacent catchments: the role of soil $\mathrm{Ca}$ and forest vegetation. Global Change Biology, 12, 364-381.

Małek S., Astel A. 2007. The effect of stand age on throughfall chemistry in spruce stands in the Potok Dupniański Catchment in the Silesian Beskid Mountains, Southern Poland. Short Communication. The Scientific World Journal, 7, 181-191.

Małek S., Krakowian K. 2009a. The effect of environmental conditions on surface water quality in the Zimnik and Czyrna catchments of the Beskid Śląski. Journal of Water Land and Development, 13, 205-223.
Małek S., Krakowian K. 2009b. Analyse of water suitable for drinking from sources in Zimnik and Czyrna in the Silesian Beskid (in Polish with English summary). Ochrona Środowiska i Zasobów Naturalnych, 38, 239-247.

Małek S. 2009. Sustainability of Picea abies of Istebna provenance in Dupniański Stream catchment as dependent on stand age class. Dendrobiology, 61 Suppl., 95-104.

Małek S., Astel A., Krakowian K., Opałacz J. 2010. Evaluation of springs water quality in the Skrzyczne and Barania Góra Mts. area (in Polish with English summary). Sylwan, 154 (7), 499-505.

Małek S., Krakowian K. 2012. The effect of deforestation on spring water chemistry on Skrzyczne (Silesian Beskid Mountains, Poland). Journal of Forest Science, 58 (7), 308-313.

Małek S., Barszcz J., Majsterkiewicz K. 2012. Changes in the threat of spruce stand disintegration in the Beskid Śląski and Żywiecki Mts in the years 2007-2010. Journal of Forest Science, 58 (12), 519-529.

Nowak A. 2002. Opis Mapy Hydrograficznej M34-57-A. [Hydrographical Map.] Węgierska Górka, GUGiK Częstochowa.

Sienkiewicz J., Kucharska K., Wawrzoniak T. 1995. Quantitative and qualitative changes of water resources in deforested mountainous areas (in Polish). Sylwan, 12, 51-60.

Siwek J., Rzonca B., Jaśkowiec B., Plenzler J., Płaczkowska E. 2013. Natural factors affecting the chemical composition of water in the catchment of Wołosatka Stream (High Bieszczady Mts.). In: The Carpathians: Integrating Nature and Society Towards Sustainability (eds.: J. Kozak, K. Ostapowicz, A. Bytnerowicz, A. Wyżga). Environmental Science and Engineering, 151-159. 